\title{
TISSUE DISTRIBUTION OF C14 AFTER THE INTRAVENOUS INJECTION OF LABELED CHYLOMICRONS AND UNES- TERIFIED FATTY ACIDS IN THE RAT
}

\author{
BY JOSEPH H. BRAGDON AND ROBERT S. GORDON, JR.
}

(From the Laboratory of Cellular Physiology and Metabolism, National Heart Institute, National Institutes of Health, Bethesda, Md.)

(Submitted for publication November 18, 1957; accepted December 26, 1957)

Chylomicrons, labeled in the triglyceride moiety with palmitic acid-1- $\mathrm{C}^{\mathbf{1 4}}$, were injected intravenously into fasting dogs by Havel and Fredrickson (1). They showed that the chylomicrons were rapidly removed from the plasma. The radioactivity did not reappear to any significant degree in the alpha or beta lipoproteins of the plasma, but did reappear as unesterified fatty acid bound to albumin (UFA). There was no actual increase in UFA concentration but the specific activity of this fraction exceeded 10 per cent of that of the the triglyceride fatty acid injected. They concluded that hydrolysis of the chylomicrons occurred in some extravascular compartment. It therefore seemed desirable to determine if possible the anatomic sites of removal of the chylomicrons. To this end, rats were injected with rat chylomicrons labeled in the triglyceride moiety with palmitic acid-1- $\mathrm{C}^{\mathbf{1 4}}$, and the tissue distribution of the label was compared with its distribution following the injection of palmitic acid-1-C ${ }^{14}$ bound to albumin (UFA).

We have previously reported (2) that although the nutritional state of the rat does not influence the rate of removal of chylomicrons from the blood, carbohydrate feeding strongly inhibits the oxidation of both chylomicrons and albuminbound UFA $(3,4)$. We therefore decided to determine whether carbohydrate feeding would influence the tissue distribution of the injected chylomicrons or UFA.

\section{METHODS}

Donor rats, the cysternae chyli in which had been cannulated on the previous day, were given about $50 \mu \mathrm{c}$. of potassium palmitate-1-C $\mathrm{C}^{\mathbf{1 4}}$ in a few $\mathrm{ml}$. of water by stomach tube. The donor rats were offered their usual commercial pellet diet and physiologic saline to drink. No carrier fat was added to the diet of the donor for Experiment I, but olive oil was mixed with the diet of the donor for Experiment II. The chyle was collected in an ice bath. The following day, after expression of the clot, the chyle was layered under $0.15 \mathrm{M}$ salt solu- tion and centrifuged for 30 minutes at approximately 100,000 times G. The chylomicrons were thereby concentrated at the top of the centrifuge tube, where they were readily separated from the residual chyle proteins. They were washed once more through saline by a second centrifugation. Analysis of one preparation showed that 97 per cent of the radioactivity was contained in the triglyceride moiety, and that most of the remainder was in the phospholipids, thus confirming the findings of previous investigators $(1,5)$.

UFA was prepared for injection as follows: Approximately $3 \mathrm{mg}$. of palmitic acid-1-C $\mathrm{C}^{\mathrm{1t}}$ containing about 10 $\mu c$. of radioactivity was dissolved in $1 \mathrm{ml}$. of ethanol in a small flask. A moderate excess of $0.02 \mathrm{~N} \mathrm{NaOH}$ was added, and the mixture evaporated to dryness. The residue of sodium palmitate was dissolved in $1 \mathrm{ml}$. of distilled water by gentle heating, cooled to approximately $40^{\circ} \mathrm{C}$., and $9 \mathrm{ml}$. of rat serum at $4^{\circ} \mathrm{C}$. was added suddenly with vigorous agitation. No crystallization of sodium palmitate was observed. The serum was submitted to paper electrophoresis in sodium barbital buffer at $\mathrm{pH}$ 8.6. The dried paper strip was scanned for radioactivity and then stained for protein. The distribution of radioactivity coincided with that of albumin.

In Experiment I, in which the recipient rats were to be killed only 10 minutes after injection, it was anticipated that significant quantities of the injected chylomicrons might still be present in the recipients' plasma. It therefore became desirable to know the quantity of plasma present in each tissue so that the radioactivity contributed by the plasma could be subtracted from the observed tissue activity to give the amount of activity actually cleared by that tissue. For that purpose, about $50 \mu \mathrm{c}$. of radioiodinated human serum albumin (RISAQ) was added to $1 \mathrm{ml}$. of normal rat serum, the mixture incubated at room temperature, and exhaustively dialyzed to remove unbound $\mathrm{I}^{181}$. This material was then added to $5 \mathrm{ml}$. of washed chylomicrons and to $5 \mathrm{ml}$. of the UFA preparation. In Experiment II, in which the recipient rats were to be permitted to survive 200 minutes after injection, no radioiodinated serum albumin was used.

The experimental animals were 12 male SpragueDawley rats, weighing between 210 and 225 grams at the time of injection. Food was removed from their cages 20 hours previously. Carbohydrate-fed animals were offered 10 per cent glucose in half-strength physiologic saline. During the night preceding the experiment, each consumed at least $120 \mathrm{ml}$. of this preparation. In Ex- 
DISTRIBUTION OF INJECTED CHYLOMICRONS AND FATTY ACIDS

TABLE I

The specific activity of tissues* 10 minutes after the injection of $C^{14}$-labeled chylomicrons or unesterified fatty acid

\begin{tabular}{lccccccccc}
\hline \multicolumn{1}{c}{ Rat No. } & $\mathbf{1}$ & $\mathbf{2}$ & $\mathbf{3}$ & $\mathbf{4}$ & $\mathbf{5}$ & $\mathbf{6}$ & $\mathbf{7}$ & $\mathbf{8}$ \\
\hline Nutritional state & CHO† & CHO & CHO & CHO & Fast & Fast & Fast & Fast \\
Lipid injected & Chylo & Chylo & UFA & UFA & Chylo & Chylo & UFA & UFA \\
Liver & 12.0 & 10.2 & 24.3 & 17.9 & 19.0 & 23.4 & 12.7 & 17.1 \\
Muscle & 1.6 & 1.6 & 1.9 & 2.1 & 0.7 & 0.4 & 1.2 & 1.5 \\
Fat & 12.4 & 12.6 & 0.5 & 0.3 & 1.3 & 2.9 & 0.8 & 0.6 \\
Spleen & 8.2 & 6.9 & 4.0 & 4.3 & 7.2 & 14.0 & 1.7 & 1.8 \\
Lung & 4.3 & 5.9 & 10.2 & 14.1 & 3.9 & 5.1 & 5.6 & 6.8 \\
Kidney & 1.8 & 2.2 & 7.4 & 7.9 & 1.9 & 3.3 & 3.6 & 5.9 \\
Heart & 4.8 & 4.6 & 16.0 & 16.0 & 15.1 & 22.0 & 3.0 & 4.1 \\
Brain & 0.1 & 0.0 & 0.3 & 0.4 & 0.3 & 0.5 & 0.3 & 0.4 \\
\hline
\end{tabular}

* Expressed as cpm times $10^{-3}$ per gram wet weight corrected for plasma content and for dose.

$+\mathrm{CHO}=$ Carbohydrate-fed.

$\ddagger$ Chylo $=\mathrm{C}^{14}$-labeled chylomicrons.

\&FA $=$ Unesterified fatty acid.

periment $\mathrm{I}$, each received $2 \mathrm{ml}$. of 50 per cent glucose solution by stomach tube one hour before the injection. The fasted animals were offered half-strength saline and similarly received water by stomach tube.

Each animal received approximately $1 \mu \mathrm{c}$. of $\mathrm{C}^{14}$ as either chylomicrons or UFA in a total volume of $1 \mathrm{ml}$. by injection into a tail vein. The chylomicron dose expressed as total lipid (6) was $18 \mathrm{mg}$. in Experiment I and $44 \mathrm{mg}$. in Experiment II. After 10 minutes and 200 minutes, respectively, in the two experiments, the animals were anesthetized with intravenous sodium pentobarbital. Five ml. of blood was withdrawn from the abdominal aorta into a syringe containing dry heparin. The organs and tissues were removed, washed in saline, blotted dry, weighed, and cut up into ethanol-acetone $(1: 1)$ as rapidly as possible in the following order: piece of liver, spleen, epididymal fat bodies, kidneys, right adductor muscle, heart ventricles, lungs, and brain. The remainder of the liver was weighed and discarded. The carcass and remaining viscera were put through a meat grinder and then extracted in 3 liters of ethanolacetone in a Waring blendor for three minutes. All tissues were in fixatives within 10 minutes following the injection of anesthetic. The organ and tissue samples were extracted in about $45 \mathrm{ml}$. of ethanol-acetone in a smaller blendor, and the extracts were transferred with washings to graduated centrifuge tubes, where they were brought to a final volume of $50 \mathrm{ml}$. Ethanol-acetone extracts of the injected material and of the plasma were also made. On the following day, the extraction mixtures were centrifuged, and aliquots of the ethanol-acetone extracts were evaporated under air at $57^{\circ} \mathrm{C}$. In the case of serum extracts, a drop of olive oil was added, as it had been previously demonstrated that UFA may sublime under these conditions if there is not sufficient carrier fat. The dried lipids were then taken up in a final volume of $10 \mathrm{ml}$. of toluene and centrifuged briefly for clarification. For $\mathrm{C}^{14}$ counting $3 \mathrm{ml}$. of the toluene extracts was added to $10 \mathrm{ml}$. of a 0.4 per cent solution of diphenyloxazole in toluene and counted at $-10^{\circ} \mathrm{C}$. in a Packard Tri-Carb scintillation counter. In order to correct for any possible contamination of the toluene by $\mathrm{I}^{181}$, another $3 \mathrm{ml}$. aliquot was counted in a thalliumactivated sodium iodide well-type scintillation counter. $\mathrm{I}^{131}$ was found in only insignificant quantities and no corrections were necessary.

For determination of the $\mathrm{I}^{131}$ content of the tissues, the protein precipitates of the original extracts were dissolved in $10 \mathrm{ml}$. of 25 per cent $\mathrm{KOH}$ in 50 per cent ethanol. After standing for several days at room temperature, they were brought to a final volume of $15 \mathrm{ml}$. with water. All material dissolved completely, except

TABLE II

The recovery and distribution of $C^{14} 10$ minutes after the injection of labeled chylomicrons or unesterified fatty acid

\begin{tabular}{|c|c|c|c|c|c|c|c|c|}
\hline Rat No. & 1 & 2 & 3 & 4 & 5 & 6 & 7 & 8 \\
\hline $\begin{array}{l}\text { Nutritional state } \\
\text { Lipid injected } \\
\text { Per cent of dose recovered as lipid- }\end{array}$ & $\begin{array}{l}\text { CHO* } \\
\text { Chylo* }\end{array}$ & $\begin{array}{l}\text { CHO } \\
\text { Chylo }\end{array}$ & $\begin{array}{l}\text { CHO } \\
\text { UFA* }\end{array}$ & $\begin{array}{l}\text { CHO } \\
\text { UFA }\end{array}$ & $\begin{array}{l}\text { Fast } \\
\text { Chylo }\end{array}$ & $\begin{array}{l}\text { Fast } \\
\text { Chylo }\end{array}$ & $\begin{array}{l}\text { Fast } \\
\text { UFA }\end{array}$ & $\begin{array}{l}\text { Fast } \\
\text { UFA }\end{array}$ \\
\hline soluble $\mathrm{C}^{14}$ & 93 & 85 & 86 & 87 & 70 & 72 & 41 & 54 \\
\hline $\begin{array}{l}\text { Per cent of dose remaining in plasma } \\
\text { Per cent of cleared activity found in: }\end{array}$ & 38 & 40 & 1 & 1 & 41 & 36 & 1 & 1 \\
\hline Liver & 19 & 15 & 30 & 26 & 21 & 21 & 14 & 16 \\
\hline Muscle & 23 & 23 & 29 & 31 & 9.7 & 5.7 & 16 & 21 \\
\hline Fat & 25 & 36 & 1.3 & 0.8 & 3.6 & 4.3 & 1.1 & 1.1 \\
\hline Spleen & 1.1 & 0.9 & 0.4 & 0.6 & 1.0 & 1.3 & 0.2 & 0.3 \\
\hline Lung & 0.8 & 0.8 & 1.7 & 2.1 & 0.6 & 0.7 & 0.6 & 0.8 \\
\hline Kidney & 0.3 & 0.6 & 1.8 & 1.7 & 0.5 & 0.7 & 0.9 & 1.2 \\
\hline Heart & 0.5 & 0.5 & 1.6 & 1.6 & 1.5 & 2.2 & 0.3 & 0.3 \\
\hline
\end{tabular}

* See footnotes to Table I for identification of these abbreviations. 
TABLE III

The specific activity of tissues* 200 minutes after the injection of $C^{14}$-labeled chylomicrons or unesterified fatty acid

\begin{tabular}{lccll}
\hline \hline \multicolumn{1}{c}{ Rat No. } & 9 & 10 & 11 & 12 \\
\hline Nutritional state & CHO† & CHO & CHO & CHO \\
Lipid injected & Chylo $\dagger$ & Chylo & UFA $\dagger$ & UFA \\
Liver & 11.0 & 11.4 & 6.4 & 6.6 \\
Muscle & 0.7 & 0.7 & 2.1 & 2.3 \\
Fat & 19.2 & 11.8 & 0.6 & 1.6 \\
Spleen & 2.9 & 3.7 & 2.7 & 4.5 \\
Lung & 3.0 & 3.1 & 6.6 & 8.4 \\
Kidney & 2.3 & 2.0 & 4.5 & 6.4 \\
Heart & 2.3 & 3.1 & 3.6 & 7.1 \\
Brain & 0.1 & 0.1 & 0.2 & 0.2
\end{tabular}

* Expressed as cpm times $10^{-3}$ per gram wet weight corrected for plasma content and for dose.

$\dagger$ See Table I for identification of these abbreviations.

the glycogen in the livers of carbohydrate-fed animals. Aliquots were counted in the well-type scintillation counter.

In some preliminary experiments, two portions of the same liver were compared. Similarly, perirenal fat was compared with epididymal fat in the same animal. The differences in $\mathrm{C}^{\mathbf{4}}$ content per gram of tissue were of the same magnitude as those reported here between similarly treated animals.

\section{RESULTS}

The amount of plasma contained in each tissue sample was determined by the $I^{131}$ content of the sample. The amount of $\mathrm{C}^{14}$ radioactivity contributed by this amount of plasma was then subtracted from the observed $\mathrm{C}^{14}$ activity. The $\mathrm{C}^{14}$ activity was also corrected for dose, so that the data for all animals are directly comparable. For this purpose, the "dose" was considered to be only that radioactivity which had been cleared from the blood. These corrections involved significant quantities only in the animals killed 10 minutes after receiving chylomicrons, as in all other animals the plasma contained relatively little radioactivity. The tissue specific activity, presented in Tables I and III, thus represents the observed $\mathrm{C}^{14}$ activity per gram of wet tissue corrected for plasma content and for "dose."

The recovery and distribution data are presented in Tables II and IV. The percentage of $\mathrm{C}^{14}$ recovered was determined from the sum of the observed radioactivity in the blood withdrawn, in each organ and tissue removed, and in the carcass. The percentage of the dose remaining in the plasma was calculated after multiplying the activity found in $1 \mathrm{ml}$. of plasma by the plasma volume, as determined by $\mathrm{I}^{131}$ dilution. The percentage of cleared activity found in the several tissues was derived by multiplying the activity per gram by the total weight of that tissue and dividing by the cleared "dose." Organ weights were determined directly. Body fat was determined by chemical analysis of the toluene carcass extract (6). No correction was made for water content of the sample of adipose tissue weighed. It should be realized that the fat extracted from the carcass included small amounts of fat from tissues other than adipose tissue. Muscle mass was estimated as 45 per cent of the body weight (7).

\section{DISCUSSION}

\section{Recovery}

The fact that 85 to 93 per cent of the injected activity were recovered after 10 minutes in the fed animals shows that the methods used were adequate. Ten minutes after injection in the fasting state, about 60 per cent of the chylomicron activity and 99 per cent of the UFA activity had been cleared from the blood. In both situations,

TABLE IV

The recovery and distribution of $C^{14} 200$ minutes after the injection of labeled chylomicrons or unesterified fatty acid

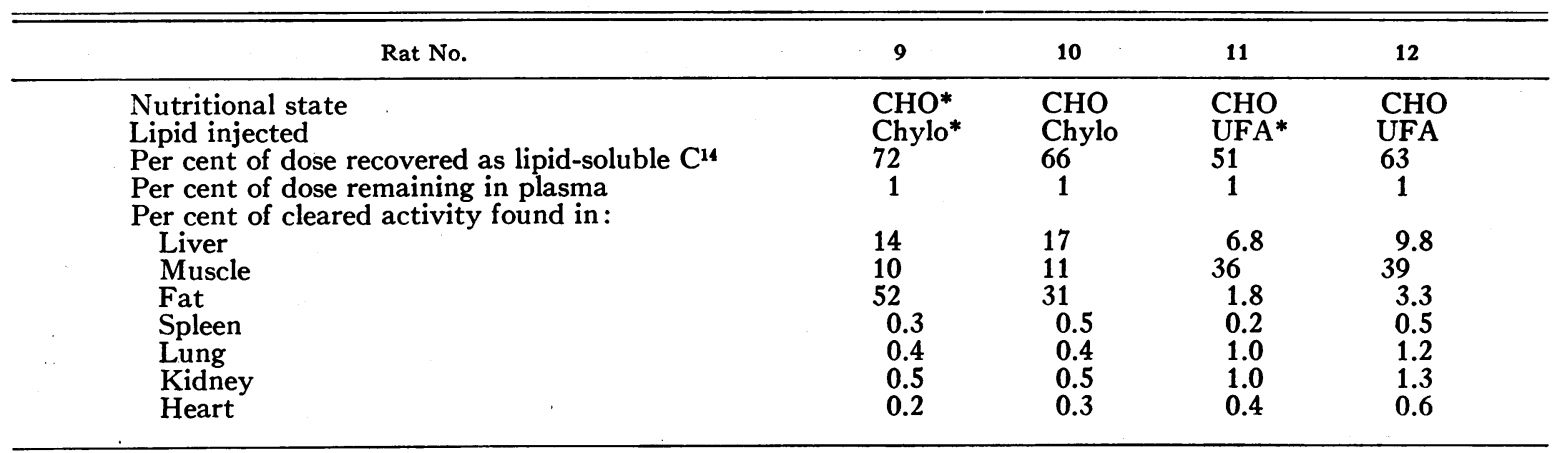

* See Table I for identification of these abbreviations. 
about half of the cleared activity was no longer recoverable as lipid-soluble $\mathrm{C}^{14}$. We have reported previously $(3,4)$ that in similarly treated rats approximately 5 and 19 per cent, respectively, of the injected radioactivity was expired as $\mathrm{C}^{14} \mathrm{O}_{2}$ within 10 minutes of injection. In the experiments reported here, more than 10 minutes elapsed from the time of injection until the processes of enzymatic degradation were halted in the tissues. It is very likely that much of the unrecovered activity was present in the form of bicarbonate and metabolic intermediates.

The sparing action of carbohydrate on fatty acid oxidation was first shown by Lossow and Chaikoff (8), who measured $\mathrm{C}^{14} \mathrm{O}_{2}$ excretion after the intravenous injection of palmitic acid-1$\mathrm{C}^{14}$ both as free acid and as triglycerides in synthetic emulsions. In our previous reports $(3,4)$ we showed the marked sparing effect of carbohydrate feeding on the oxidation of palmitic acid when administered in the more physiologic forms of chylomicrons and UFA. Carbohydrate feeding in the present experiments permitted the recovery of over 50 per cent of the injected dose as lipidsoluble $\mathrm{C}^{14}$, even after 200 minutes. The results of Experiment I confirm our previous report (2) that chylomicrons are cleared no more rapidly in the fasting animal than in the animal in positive caloric balance.

\section{Mechanism of chylomicron clearance}

In the dog experiments of Havel and Fredrickson (1) the radioactivity, the triglyceride content, and the phospholipid content of the chylomicron fraction of the recipients' sera decreased at the same rate, suggesting that the chylomicrons were being removed intact. Studies of the changes in concentration of certain lowdensity serum lipoproteins following alimentary hyperlipemia in human subjects have been interpreted, however, as indicating the conversion of chylomicrons into lipoproteins of increasing density (9). It was implied that lipid was being removed from the circulating lipoproteins. Although it has been suggested that the clearing factor is the enzyme responsible for this phenomenon, the enzyme can rarely be demonstrated in the plasma in appreciable quantities, except following the injection of heparin or heparinoids. In the present experiments, if intravascular hydrolysis of triglyceride to UFA were the major pathway for the clearance of chylomicrons, one would expect the distribution of labeled fatty acid to be the same whether injected as chylomicron or as UFA. Such was not the case. After chylomicron injection in carbohydrate-fed animals from 25 to 50 per cent of the cleared activity were found in the body fat, whereas after UFA injection, less than 4 per cent of the cleared activity appeared there, proving that chylomicrons were being removed by adipose tissue without prior hydrolysis.

\section{Distribution of chylomicrons}

In the carbohydrate-fed rats, even 200 minutes after the injection of chylomicrons, approximately 70 per cent of the injected radioactivity was recovered as lipid-soluble $\mathrm{C}^{14}$. It is of interest to compare the tissue distribution of this activity at 200 minutes with that at 10 minutes. The specific activity of liver, adipose tissue, and kidney, corrected for activity actually cleared, remained essentially unchanged. That of muscle, spleen, lung, and heart decreased approximately 50 per cent. These findings indicate that during the time interval there had been relatively little redistribution of fatty acid activity. In the former group of tissues there had apparently been storage of chylomicron activity, and in the latter group there had been a loss of about 50 per cent of that cleared, probably by oxidation.

The distribution of chylomicrons in the fasting state can be compared with the distribution after carbohydrate feeding, only in the 10 minute experiment. In the fasting state, the specific activity in the liver and in the heart muscle are significantly higher than they are in the fed animals in spite of the fact that in the fasting state the total activity recovered was considerably less. These differences indicate that the nutritional state of the animal determines to some extent the sites at which chylomicrons are removed. The opposite finding, i.e., less radioactivity in the muscle of the fasting animal than in that of the fed, does not carry the same implication, for it is possible that the amount cleared by muscle in the fasting animal was actually greater, but that more had been oxidized. In the case of fat, the specific activity in the fasting state was less than 20 per cent of the specific activity found in the fed animals. Again there are two possible explanations: either less was cleared by the depots in the fasting state, 
or the same amount was cleared but the radioactivity was rapidly redistributed, presumably as UFA. Adipose tissue is known to be rich in the enzyme lipoprotein lipase (10). The caloric requirements of the depots are presumably so small that the possibility of local oxidation may be neglected. It is not necessary to assume that 80 per cent of the fatty acids of the depots underwent exchange in this short period of time, as the mixing of labeled fatty acid with depot fatty acid was probably not complete.

\section{Distribution of unesterified fatty acid}

The very rapid disappearance of 99 per cent of the labeled UFA from the circulating blood, and the long persistence of the remaining 1 per cent indicate that an exchange occurs between plasma UFA and the fatty acids of a tissue pool. This tissue pool must contain about 100 times as much exchangeable fatty acid as does the plasma compartment. Adipose tissue does not contribute significantly to this tissue pool, as is shown by the apparent size of the pool (adipose tissue contains about 10,000 times as much fatty acid as does the circulating UFA fraction) and by the failure of the injected labeled UFA to enter the depot fat, even in rats maintained for 200 minutes after injection. We suspect that the 10 minute distribution data are, in part, indicative of the relative blood flow of each tissue, whereas the 200 minute figures reflect more accurately the amount of exchangeable fatty acid present in the different tissues. Thus, at 10 minutes in carbohydrate-fed rats, the most.heavily labeled tissues are liver, lung, kidney, and heart, whereas, at 200 minutes, the specific activity of muscle was comparable to those of the other tissues and because of its greater mass, muscle contained the largest fraction of the total recoverable activity. The tissue radioactivities observed in fasted animals at 10 minutes must represent a complex function of blood flow, tissue pool size, and oxidative rate, and cannot as yet be interpreted in detail.

\section{SUM MARY}

Rats were injected intravenously with either rat chylomicrons, labeled in the triglyceride moiety with palmitic acid-1-C $\mathrm{C}^{\mathbf{1 4}}$, or with the unesterified labeled acid bound to serum albumin (UFA). Some of the recipient rats were fasting and some were carbohydrate-fed. They were killed 10 and
200 minutes after injection, and the tissues were analyzed for their $\mathrm{C}^{14}$ content. Carbohydrate feeding spared the oxidation of both lipid forms and greatly increased the recovery of lipid-soluble $\mathrm{C}^{14}$. The tissue distribution of the chylomicron label was quite different from that of the UFA label. This was interpreted as proving that the bulk of the chylomicrons do not undergo intravascular hydrolysis, and as indicating that they are removed intact from the circulation. Cleared chylomicron activity in the fasting state was found primarily in the liver and, after carbohydrate feeding, primarily in the depots.

Plasma UFA rapidly exchanges with a tissue pool, which contains about 100 times as much exchangeable fatty acid as does the plasma. The fat depots are not a significant part of this pool, the bulk of which is in liver and muscle.

\section{REFERENCES}

1. Havel, R. J., and Fredrickson, D. S. The metabolism of chylomicra. I. The removal of palmitic acid 1-C $\mathrm{C}^{14}$ labeled chylomicra from dog plasma. J. clin. Invest. 1956, 35, 1025.

2. Bragdon, J. H., Havel, R. J., and Gordon, R. S., Jr. Effects of carbohydrate feeding on serum lipids and lipoproteins in the rat. Amer. J. Physiol. 1957, 189, 63.

3. Bragdon, J. H. $\quad \mathrm{C}^{14} \mathrm{O}_{2}$ excretion after the intravenous administration of labeled chylomicrons in the rat. Arch. Biochem. In press.

4. McCalla, C., Gates, H. S., Jr., and Gordon, R. S., Jr. $\mathrm{C}^{24} \mathrm{O}_{2}$ excretion after the intravenous administration of albumin-bound palmitate-1-C $\mathrm{C}^{16}$ to intact rats. Arch. Biochem. 1957, 71, 346.

5. Bloom, B., Chaikoff, I. L., Reinhardt, W. O., and Dauben, W. G. Participation of phospholipides in lymphatic transport of absorbed fatty acids. J. biol. Chem. 1951, 189, 261.

6. Bragdon, J. H. Colorimetric determination of blood lipides. J. biol. Chem. 1951, 190, 513.

7. Donaldson, H. H. The Rat, 2nd ed. rev. Philadelphia, Wistar Institute of Anatomy and Biology, Memoirs No. 6, 1924.

8. Lossow, W. J., and Chaikoff, I. L. Carbohydrate sparing of fatty acid oxidation. I. The relation of fatty acid chain length to the degree of sparing. II. The mechanism by which carbohydrate spares the oxidation of palmitic acid. Arch. Biochem. 1955, 57, 23.

9. Jones, H. B., Gofman, J. W., Lindgren, F. T., Lyon, T. P., Graham, D. M., Strisower, B., and Nichols, A. V. Lipoproteins in atherosclerosis. Amer. J. Med. 1951, 11, 358.

10. Korn, E. D., and Quigley, T. W., Jr. Studies on lipoprotein lipase of rat heart and adipose tissue. Biochim. Biophys. Acta 1955, 18, 143. 